\title{
Plant-Microbe Synergism in Floating Treatment Wetlands for the Enhanced Removal of Sodium Dodecyl Sulphate from Water
}

\author{
Momina Yasin ${ }^{1,2}$ D, Muhammad Tauseef ${ }^{3}$, Zaniab Zafar ${ }^{1,2}$, Moazur Rahman ${ }^{4}$, Ejazul Islam ${ }^{1,2}$, Samina Iqbal ${ }^{1,2}$ \\ and Muhammad Afzal 1,2,*iD
}

1 Soil and Environmental Biotechnology Division, National Institute for Biotechnology and Genetic Engineering (NIBGE), Faisalabad 38000, Pakistan; mominayasin4@gmail.com (M.Y.); zainabzafar39@gmail.com (Z.Z.); ejazulislam75@yahoo.com (E.I.); siqbaleb@gmail.com (S.I.)

2 Pakistan Institute of Engineering and Applied Sciences (PIEAS), Islamabad 44000, Pakistan

3 Department of Physics, Kohsar University, Murree 47118, Pakistan; tauseefqau@gmail.com

4 School of Biological Sciences, University of the Punjab, Quaid-i-Azam Campus, Lahore 53720, Pakistan; moaz.sbs@pu.edu.pk

* Correspondence: manibge@yahoo.com

check for updates

Citation: Yasin, M.; Tauseef, M.; Zafar, Z.; Rahman, M.; Islam, E.; Iqbal, S.; Afzal, M. Plant-Microbe Synergism in Floating Treatment Wetlands for the Enhanced Removal of Sodium Dodecyl Sulphate from Water. Sustainability 2021, 13, 2883. https://doi.org/10.3390/su13052883

Academic Editor:

Helvi Heinonen-Tanski

Received: 20 January 2021

Accepted: 2 March 2021

Published: 7 March 2021

Publisher's Note: MDPI stays neutral with regard to jurisdictional claims in published maps and institutional affiliations.

Copyright: (c) 2021 by the authors. Licensee MDPI, Basel, Switzerland. This article is an open access article distributed under the terms and conditions of the Creative Commons Attribution (CC BY) license (https:/ / creativecommons.org/licenses/by/ $4.0 /)$.

\begin{abstract}
Excessive use of detergents in wide industrial processes results in unwanted surfactant pollution. Among them, sodium dodecyl sulphate (SDS) has well-known history to be used in pharmaceutical and industrial applications. However, if discharged without treatment, it can cause toxic effects on living organisms especially to the aquatic life. Floating treatment wetlands (FTWs) could be a cost-effective and eco-friendly options for the treatment of wastewater containing SDS. In this study, FTWs mesocosms were established in the presence of hydrocarbons-degrading bacteria. Two plant species (Brachiaria mutica and Leptochloa fusca) were vegetated and a consortium of bacteria (Acinetobacter sp. strain BRSI56, Acinetobacter junii strain TYRH47, and Acinetobacter sp. strain CYRH21) was applied to enhance degradation in a short-time. Results illustrated that FTWs vegetated with both plants successfully removed SDS from water, however, bacterial augmentation further enhanced the removal efficiency. Maximum reduction in SDS concentration (97.5\%), chemical oxygen demand $(92.0 \%)$, biological oxygen demand (94.2\%), and turbidity $(99.4 \%)$ was observed in the water having FTWs vegetated with B. mutica and inoculated with the bacteria. The inoculated bacteria showed more survival in the roots and shoots of B. mutica as compared to L. fusca. This study concludes that FTWs have the potential for the removal of SDS from contaminated water and their remediation efficiency can be enhanced by bacterial augmentation.
\end{abstract}

Keywords: hydroponic root mats; plant-bacteria partnership; detergents; phytoremediation; wastewater

\section{Introduction}

The consumption of detergents is increasing due to industrialization and urbanization, which results in the discharge of a higher concentration of these pollutants in the environment. Detergents are synthetic organic compounds that are used extensively in different cleansing activities such as car washing facilities, laundries, household as well as in many industries such as cosmetics, textile, paper, etc. [1-3]. These compounds can cause complications in sewage treatment due to their high foaming ability, lower oxygenation potential, and subsequently kill aquatic organisms including fish [4,5]. A typical detergent contains surfactants (10 to $20 \%$ ), bleach (7\%), phosphate builders $(50 \%)$, and additives (23-33\%). Among these, surfactants are the components that are responsible for the cleaning action of detergents [6,7]. Surfactant molecules are composed of a polar head group which may either be charged or uncharged and a non-polar hydrocarbon tail [8-10]. The hydrophilic and hydrophobic properties of these molecules make them suitable for a cleansing purpose [11]. One of the main surfactants in detergents is sodium dodecyl 
sulfate (SDS) or sodium lauryl sulphate (SLS), which has extensive applications in various sectors [12-15]. Further, they are used to modify many adsorbents to increase the efficiency of removing many pollutants. Traditionally, surfactants have been categorized into four types based on the hydrophilic heads, namely, anionic, cationic, amphoteric, and nonionic [16]. Among them, ionic surfactants have received tremendous attention because they are very popular, strongest, and inexpensive agents $[17,18]$. They have a negative charge on their hydrophilic end that helps the surfactant molecules lift and suspend particles in the micelles. In the micelle, the surfactants are oriented with their charged head groups toward the solid surface while the hydrophobic hydrocarbon chains protrude into aqueous phase followed by their effective removal from the contaminated environment $[18,19]$. SDS is an anionic surfactant that exhibits these properties. However, different researchers have also reported the toxic effects of SDS on living organisms especially fish and microbes like yeast and bacteria. It is also toxic to mammals such as human beings though to a lesser extent [20].

Many traditional methods, such as coagulation, filtration with coagulation, distillation, precipitation, ozonation, adsorption, ion exchange, sedimentation, filtration, reverse osmosis, and advanced oxidation have been reported for the removal of SDS from the wastewater [21-23]. However, these methods are less sustainable because of their high operational, capital, and maintenance costs [24-26]. Moreover, one of the drawbacks of these methods is the generation of toxic sludge which may produce secondary pollution [27-29]. Therefore, remediation of the wastewater by a technology that has low capital and operational costs, self-sustaining, and environmentally friendly is required [30,31]. Recently, the use of floating treatment wetlands (FTWs) is considered a promising method for the treatment of contaminated water [32-36]. These FTWs are small artificial selfbuoyant mats or hydroponics platforms $[37,38]$ that permit the aquatic plants to grow in water that is typically too deep for them [6]. These have been considered applicable and proved to be very effective and suitable in the restoration of contaminated water due to their multi-pollutant treatment capability, low cost, easy operation and do not require any technical skills for operation and maintenance [24,39-41]. In FTWs, plants' roots provide a wide surface area for the growth and proliferation of microorganisms which results in the formation of biofilm on the roots [42-44]. The biofilm is the place where the majority of nutrients uptake and organic pollutants degradation takes place in FTWs $[45,46]$. The microorganisms contain certain enzymes such as alkyl sulfatases which initiate the degradation of detergents by catalyzing the hydrolytic cleavage of ester bonds to release inorganic sulfates [47-50]. The resulting parental alcohol upon $\beta$-oxidation is degraded and transformed into water and carbon dioxide [1].

Brachiaria mutica (Para grass) and Leptochloa fusca (Kallar grass) are the two different plant species used in the remediation of contaminated soil and water [42,43]. These are common salt-tolerant grasses with an extensive root system and biomass that allow them to withstand stress conditions, such as wastewater [42,43]. The present work aimed to evaluate the effect of inoculation of the bacteria in FTWs, vegetated with B. mutica and L. fusca, on the remediation of SDS contaminated water. We selected SDS as a model compound because it is abundantly found in the domestic wastewater. It has extensive application in cleaning and hygiene products such as household detergents, car wash shampoos, soaps, and toothpaste [15]. The adsorption potential of SDS on various substrates is already investigated [16-18]; nevertheless, removal efficiency by CWs from the contaminated wastewater is still unknown. In this study, we investigated the treatment performance of the system by evaluating temporal decrease in SDS concentration, COD, and $\mathrm{BOD}$ reduction in the water. Moreover, the persistence of the inoculated bacteria was monitored in the water, and root and shoot of the plants. 


\section{Materials and Methods}

\subsection{Bacterial Strains}

Seven bacterial strains (Bacillus pumilus strain RT1, Acinetobacter sp. strain BRSI56, Acinetobacter junii strain TYRH47, Acinetobacter sp. strain CYRH21, Pseudomonas aeruginosa strain BRRI54, Burkholderia phytofirmans PsJN, and Klebsiella sp. strain LCRI-87) were tested for their ability to degrade SDS. These strains were already isolated and characterized for oil degradation and plant growth promoting activities [51,52]. The strains were cultivated in an M9 medium containing $50 \mathrm{mg} \mathrm{L}-1$ SDS at $37^{\circ} \mathrm{C}$ in a shaking incubator. Their SDS degradation potential and growth were monitored. Among these, three (Acinetobacter sp. strain BRSI56, Acinetobacter sp. strain CYRH21, and B. phytofirmans PsJN) were selected based on their maximum growth and SDS degradation potential. The selected strains were grown in LB broth overnight, and their cells were harvested by centrifugation. The bacterial consortium was prepared by mixing equal numbers of cells of each strain. One hundred $\mathrm{mL}$ of this consortium was used for inoculation in each FTWs mesocosm.

\subsection{Development of FTWs}

Eighteen FTWs mesocosms were established in $50 \mathrm{~L}$ plastic drums in the vicinity of NIBGE, Faisalabad (Figure 1). For the development of FTWs, a polyethylene sheet (Jumbolon Roll) was used for preparing hydroponic mats. The octagon-shaped sheet having 3 inches thickness was drilled from the middle to make a hole for vegetation. The cuttings (20) of B. mutica and L. fusca were taken from the nursery (developed in the vicinity of NIBGE, Faisalabad), and placed in each hole, and then soil and coconut shavings were used to support the cuttings in these holes. The cuttings were allowed to grow for two months in tap water to develop fresh roots and leaves, after that the water of the pots was replaced with SDS contaminated water $\left(50 \mathrm{mg} \mathrm{L}^{-1}\right)$ and bacterial consortium $(100 \mathrm{~mL})$ was added to the required treatments. Different treatments having floating mats were: SDS contaminated water without vegetation and bacteria (C), SDS contaminated water with L. fusca (T1), SDS contaminated water with L. fusca and bacteria (T2), SDS contaminated water with B. mutica (T3), SDS contaminated water with B. mutica and bacteria (T4), and SDS contaminated water with bacteria (T5). Each treatment was in triplicate and the whole experimental setup was placed at a place having ambient conditions of temperature and light from June to August 2020.

\subsection{Water Analysis}

The water samples were collected every $24 \mathrm{~h}$ from each treatment and analyzed for $\mathrm{pH}$, turbidity, BOD, and COD as described earlier (APHA, 2005) [53]. Turbidity was determined by using Spectro Quadrant Nova 60. The benchtop digital AccumetModel$25 \mathrm{pH}$ meter (Denver Instrument, Denver, CO, USA) was used to determine the $\mathrm{pH}$. The COD was analyzed by colorimetric method using a Spectrophotometer. The BOD was determined by a 5-Day BOD test. The concentration of SDS in the water was determined spectrophotometrically as described earlier [42,43]. At first, 1 drop of $1 \%$ phenolphthalein solution was added to the solution as an indicator. Then, $1 \mathrm{M} \mathrm{NaOH}$ was added until the color was changed to pink, which was followed by the addition of $1 \mathrm{M} \mathrm{H}_{2} \mathrm{SO}_{4}$ until the solution became colorless. The chloroform and methylene blue reagents were then added in the solution. All of the procedure was done in a separatory funnel. The flasks were shaken for about $30 \mathrm{~s}$ and for the phase separation, these flasks were left for $30 \mathrm{~min}$. The chloroform layer was extracted in a $100 \mathrm{~mL}$ of Erlenmeyer flask. The procedure was repeated thrice by adding $5 \mathrm{~mL}$ of chloroform. Three layers of chloroform were obtained. The chloroform layer was extracted in a volumetric flask. The absorbance of chloroform was measured by a spectrophotometer at $652 \mathrm{~nm}$ against the blank chloroform. The blank was prepared by adding $5 \mathrm{~mL}$ phosphate buffer solution, $2 \mathrm{~mL}$ cationic dye (methylene blue) solution, and $5 \mathrm{~mL}$ of extracting solvent (chloroform) in $100 \mathrm{~mL}$ distilled water. Standard solution was prepared by adding $5 \mathrm{~mL}$ phosphate buffer solution, $2 \mathrm{~mL}$ the dye solution, and $5 \mathrm{~mL}$ 
of extracting solvent in $100 \mathrm{~mL}$ of $10 \mathrm{ppm}$ standard SDS solution. The calculations were performed as follows:

Standard Factor $=10 / \mathrm{OD}$ of standard solution

Detergents $(\mathrm{mg} / \mathrm{L})$ in wastewater sample $=\mathrm{OD}$ of sample $\times \mathrm{SF}$
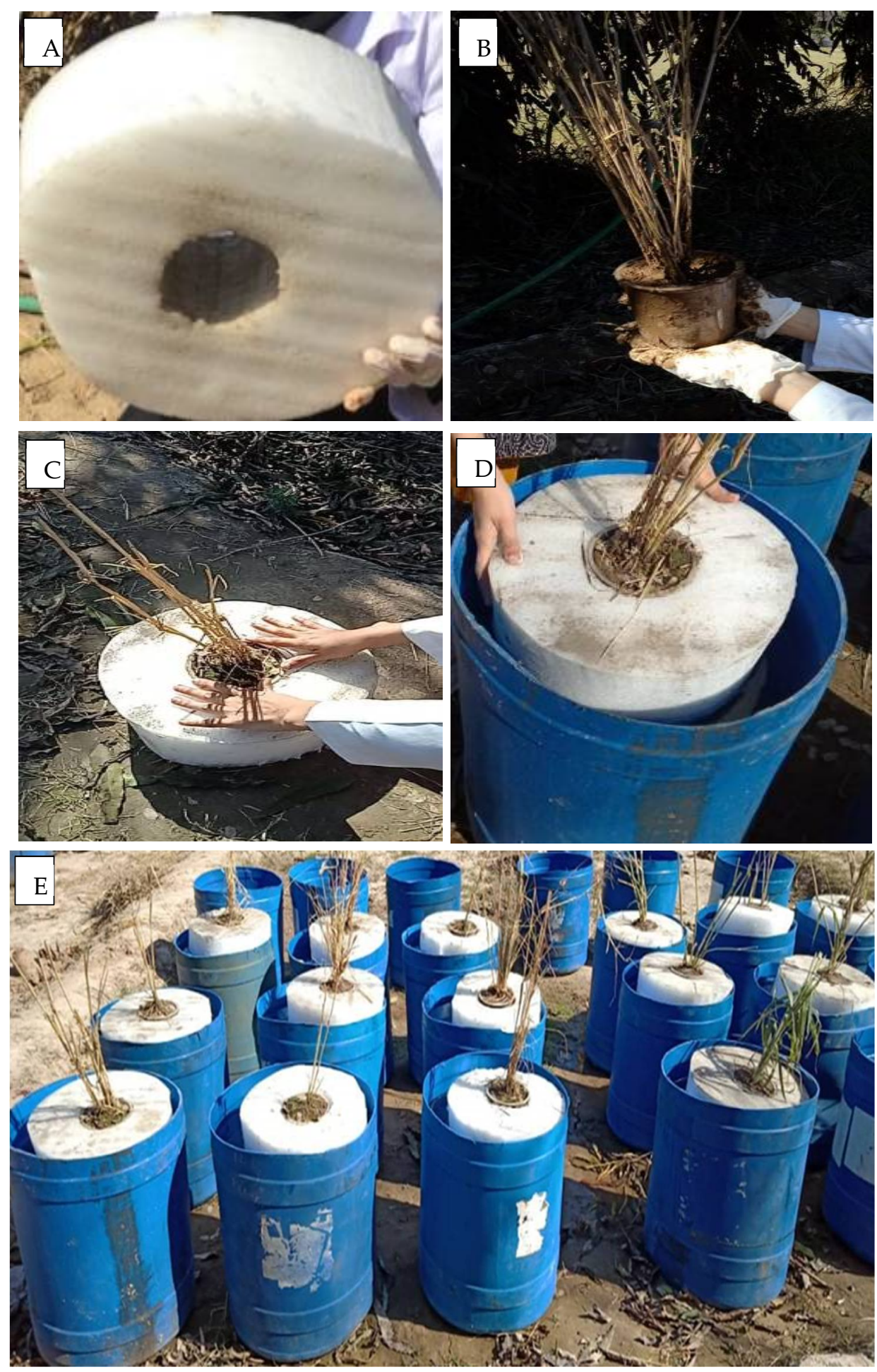

Figure 1. (A) Development of floating treatment wetlands. Buoyant mat, (B) vegetation of the plant in plastic pot, (C) fixing of the pot in the mat, (D) placement of the vegetated mat in the tank, (E) and different treatments for the remediation of SDS contaminated water. 


\subsection{Determination of Persistence of Inoculated Bacteria}

The number of inoculated bacteria in the water was determined by the plate count method as described earlier [42,43]. Briefly, the water samples were plated on M9 agar plates containing SDS $\left(50 \mathrm{mg} \mathrm{L}^{-1}\right)$. At the end of the experiment, the roots, and shoots of T3 treatments were collected and surface sterilized by $70 \%$ ethanol followed by washing with bleach $(1 \%, v / v)$ and rinse with autoclaved distilled water three times. The surfacesterilized roots and shoots were then homogenized in $0.9 \%(w / v) \mathrm{NaCl}$ solution and plated on the M9 media containing SDS $\left(50 \mathrm{mg} \mathrm{L}^{-1}\right)$. The plates were incubated at $37^{\circ} \mathrm{C}$ for $48 \mathrm{~h}$. The number of colonies forming units (CFUs) was counted and the identity of the isolates was compared with the inoculated strains by restriction fragment polymorphism analysis as described earlier [32-36].

\subsection{Data Analysis}

The data were analyzed using the SPSS software package. Comparisons among treatments were carried out by one-way analysis of variance (ANOVA). Duncan's test was applied for ANOVA after testing homogeneity of variance.

\section{Results and Discussion}

\subsection{Performance Evaluation of FTWs}

The performance of FTWs with and without bacterial consortium was evaluated by analyzing the water quality parameters such as SDS, COD, BOD, $\mathrm{pH}$, and turbidity of the water samples. FTWs, vegetated with both plants, efficiently reduced the level of all the tested water quality parameters. The reduction of SDS, COD, and BOD was more in the FTWs vegetated with B. mutica and L. fusca (T1 and T3) (Figures 2-4) as compared to unvegetated treatment (C). Usually, plants can take up the organic contaminants from the environment if the water octanol partition coefficient $\left(\log \mathrm{k}_{\mathrm{ow}}\right)$ ranges between 0.5 to 3.5. The $\log \mathrm{k}_{\mathrm{ow}}$ values of SDS is 1.6 that makes it an easy compound to be taken up by the plants. This might be the reason that even vegetation alone significantly reduced the SDS concentration and other pollution parameters in the contaminated water. Nevertheless, performance of B. mutica was better than $L$. fusca which could be due to the better adaptability of B. mutica in this kind of wastewater. It is previously reported that B. mutica outperforms in the wetlands even under harsh environmental conditions for the removal of variety of organic and inorganic contaminants [41]. On the other hand, a significantly better reduction in SDS, COD, and BOD concentration (90-97.5\%) was observed in the FTWs having both vegetation and bacterial inoculation (T2 and T4) than in the FTWs having only vegetation (T1 and T3) or bacterial inoculation (T5). This could be due to the effective plant-microbe interplay in the FTWs: (1) inoculated bacteria were previously isolated from the shoot and root interior of plants so they could have already developed mechanisms of proliferation in the plant rhizo- and endosphere that allow the bacteria have helped degrade the SDS and supported the health of host plant in a synergistic manner, and (2) the bacteria possessed genes involved in pollutant degradation and plant growth promoting activities, i.e., 1-aminocyclopropane-1-carboxylate (ACC) deaminase, siderophores production, phosphorus solubilization [54-57]. Once again, maximum reduction in SDS (97.5\%), COD $(92 \%)$, and BOD $(94 \%)$ were observed in the treatments vegetated with B. mutica and bacterial inoculation. This might be attributed to the better plant-bacteria synergism in FTWs having B. mutica as compared to L. fusca. In our earlier investigations, we found that B. mutica allows proliferation of diverse and rich bacteria in the rhizo- and endosphere that overall improves the health of the host plant and degradation potential of the wetland system [42]. The reduction in COD and BOD might be related to the bacterial enzymatic activities that cause the degradation and transformation of SDS into simpler metabolites which are then taken up by the plants in the form of nutrients [41,57]. Both COD and $\mathrm{BOD}$ are important water quality parameters, and their attenuation indicates the cleaning of contaminated water [42]. Alongside, high oxygen concentration is fundamental to such environment and successful interactions among plant roots and associated bacteria 
rely on the availability of oxygen diffusion. In a well growing FTW system, vegetation could have provided oxygen in the rhizosphere through the plant roots thus allowing the microbes to nurture and ultimately leads to the degradation of contaminants $[42,54,55]$. The synergistic interactions between plants and microorganisms intensified the oxidation and reduction processes which are responsible for the removal and degradation of a wide range of contaminants [56]. These results are following the previously published findings which reported that bacterial inoculation enhanced the efficiency of FTWs [42,57].

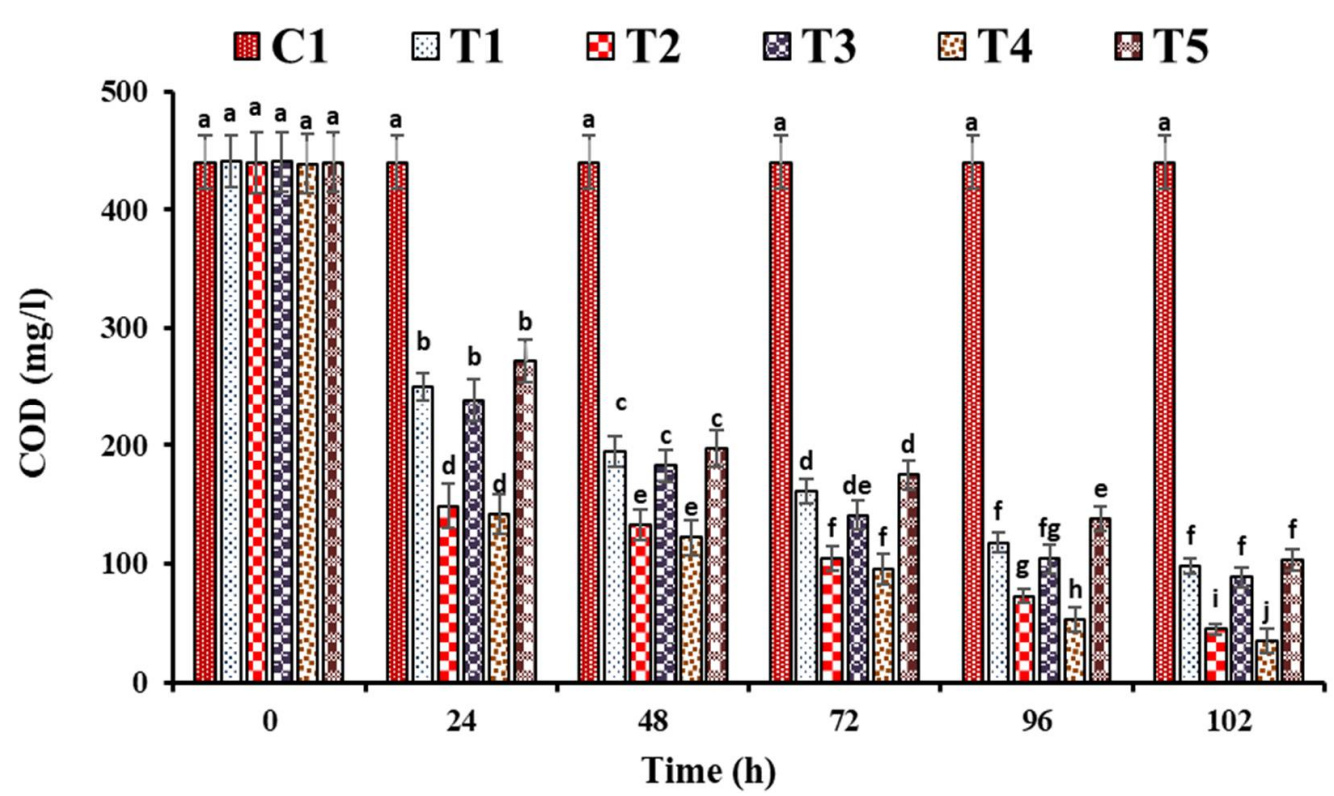

Figure 2. COD of water treated by floating treatment wetlands vegetated with L. fusca and B. mutica at different times. SDS contaminated water without vegetation and bacteria (C), SDS contaminated water with $L$. fusca (T1), SDS contaminated water with $L$. fusca and bacteria (T2), SDS contaminated water with B. mutica (T3), SDS contaminated water with B. mutica and bacteria (T4), and SDS contaminated water with bacteria (T5). Error bars indicate the standard error among the three replicates. Labels (a)-(j) indicate statistically significant differences between treatments at a 5\% level of significance.

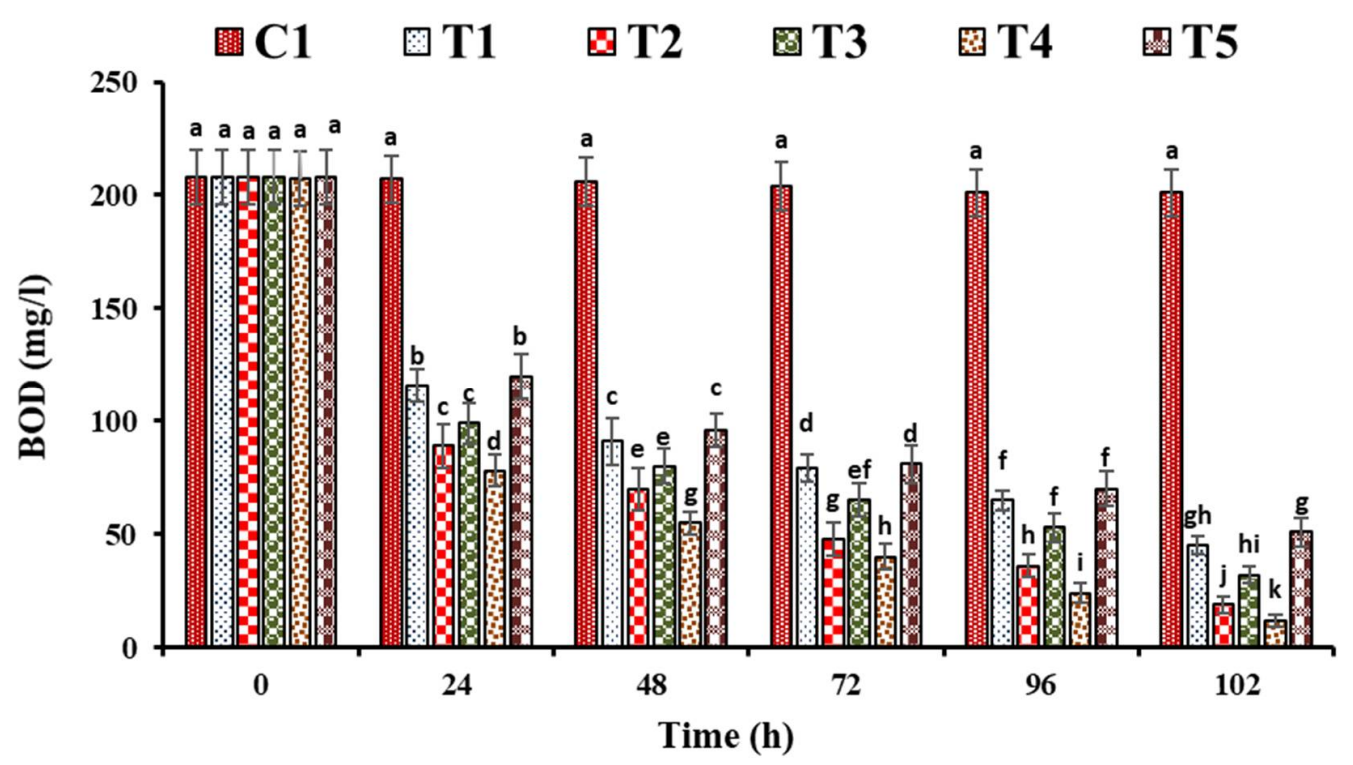

Figure 3. BOD of water treated by floating treatment wetlands vegetated with L. fusca and B. mutica at different times. SDS contaminated water without vegetation and bacteria (C), SDS contaminated water with $L$. fusca (T1), SDS contaminated water with L. fusca and bacteria (T2), SDS contaminated water with B. mutica (T3), SDS contaminated water with B. mutica and bacteria (T4), and SDS contaminated water with bacteria (T5). Error bars indicate the standard error among the three replicates. Labels (a)-(j) indicate statistically significant differences between treatments at a 5\% level of significance. 


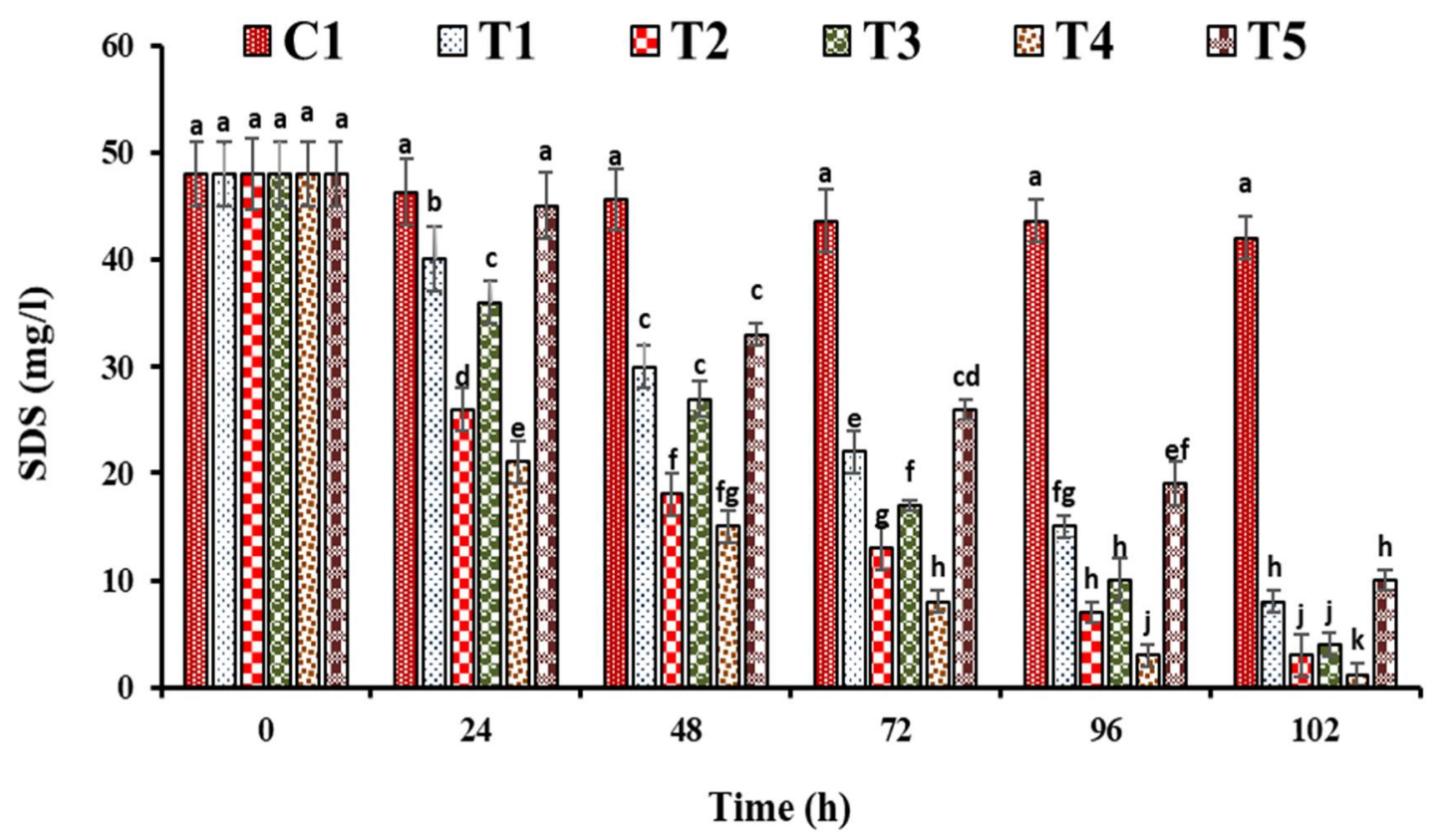

Figure 4. SDS concentrations after treatment with floating treatment wetlands vegetated with L. fusca and B. mutica at different times. SDS contaminated water without vegetation and bacteria (C), SDS contaminated water with $L$. fusca (T1), SDS contaminated water with L. fusca and bacteria (T2), SDS contaminated water with B. mutica (T3), SDS contaminated water with B. mutica and bacteria (T4), and SDS contaminated water with bacteria (T5). Error bars indicate the standard error among the three replicates. Labels (a)-(j) indicate statistically significant differences between treatments at a $5 \%$ level of significance.

In this study, $13 \%$ removal of SDS was also observed in the control when no vegetation and bacterial consortium was present. This could be attributed to natural factors such as photooxidation, adsorption, and indigenous role of microbial communities. However, the degradation was further enhanced by vegetation and bacterial inoculation. Specifically, SDS removal was enhanced to $>90 \%$ when plants and bacterial consortium was applied together. Earlier studies revealed that some bacterial species could degrade the SDS and reduced its concentration to $0.1 \%$ within 11 days [11,58-60]. On the contrary, in this study, the plant-bacterial partnership in FTWs reduced the concentration of SDS to $0.1 \%$ only in five days.

Apart from the reduction in the above-mentioned parameters, the $\mathrm{pH}$ of the SDS contaminated water was slightly decreased, i.e., from 8.6 to 7.9 in FTWs vegetated with L. fusca, and from 8.6 to 7.8 in FTWs vegetated with B. mutica (Table 1). More reduction in the $\mathrm{pH}$ was observed in vegetated wetland units as compared to unvegetated units which might be related to the production of carbon dioxide $\left(\mathrm{CO}_{2}\right)$ during roots respiration [45]. Maximum $\mathrm{pH}$ reduction was observed in the treatment having $B$. mutica and bacterial inoculation. This decrease in $\mathrm{pH}$ might be related to the degradation of SDS by microorganisms that yield $\mathrm{CO}_{2}$ that reacts with oxygen in the water and produces carbonic acid. Alongside, this reduction might have been related to the acidic root exudates as well which are released by the plants under standard conditions. Previous studies also reported $\mathrm{pH}$ reduction in water treated by FTWs vegetated with different plants [45,46]. A similar trend was observed for turbidity removal in all the treatments. However, the FTWs containing both B. mutica and bacterial inoculation showed maximum reduction $(99.4 \%)$ of turbidity (Table 1). 
Table 1. Effect of bacterial augmentation on $\mathrm{pH}$ and turbidity of SDS contaminated water treated by floating treatment wetlands vegetated with Leptochloa fusca and Brachiaria mutica.

\begin{tabular}{|c|c|c|c|c|c|c|c|c|c|c|c|c|}
\hline \multirow{3}{*}{$\begin{array}{l}\text { Time } \\
\text { (h) }\end{array}$} & \multirow{2}{*}{\multicolumn{2}{|c|}{ Control (C) }} & \multicolumn{4}{|c|}{ L. fusca } & \multicolumn{4}{|c|}{ B. mutica } & \multirow{2}{*}{\multicolumn{2}{|c|}{ T5 }} \\
\hline & & & \multicolumn{2}{|c|}{ T1 } & \multicolumn{2}{|c|}{$\mathrm{T} 2$} & \multicolumn{2}{|c|}{ T3 } & \multicolumn{2}{|c|}{ T4 } & & \\
\hline & $\mathrm{pH}$ & Turbidity & $\mathrm{pH}$ & Turbidity & $\mathrm{pH}$ & Turbidity & $\mathrm{pH}$ & Turbidity & $\mathrm{pH}$ & Turbidity & $\mathrm{pH}$ & Turbidity \\
\hline 0 & $\begin{array}{c}8.62 \\
(0.13)\end{array}$ & $\begin{array}{l}33.62 \\
(2.07)\end{array}$ & $\begin{array}{c}8.60 \\
(0.22)\end{array}$ & $\begin{array}{l}33.02 \\
(1.52)\end{array}$ & $\begin{array}{c}8.57 \\
(0.21)\end{array}$ & $\begin{array}{l}33.05 \\
(2.78)\end{array}$ & $\begin{array}{c}8.62 \\
(0.31)\end{array}$ & $\begin{array}{l}33.04 \\
(1.65)\end{array}$ & $\begin{array}{c}8.52 \\
(0.22)\end{array}$ & $\begin{array}{l}33.28 \\
(1.72)\end{array}$ & $\begin{array}{c}8.62 \\
(0.31)\end{array}$ & $\begin{array}{l}33.04 \\
(1.15)\end{array}$ \\
\hline 24 & $\begin{array}{c}8.57 \\
(0.28)\end{array}$ & $\begin{array}{l}32.43 \\
(2.19)\end{array}$ & $\begin{array}{c}8.43 \\
(0.12)\end{array}$ & $\begin{array}{l}31.08 \\
(1.23)\end{array}$ & $\begin{array}{c}8.3 \\
(0.22)\end{array}$ & $\begin{array}{l}29.28 \\
(1.55)\end{array}$ & $\begin{array}{c}8.25 \\
(0.12)\end{array}$ & $\begin{array}{l}30.47 \\
(1.53)\end{array}$ & $\begin{array}{c}8.15 \\
(0.14)\end{array}$ & $\begin{array}{l}28.08 \\
(1.56)\end{array}$ & $\begin{array}{c}8.52 \\
(0.70)\end{array}$ & $\begin{array}{l}32.05 \\
(1.23)\end{array}$ \\
\hline 48 & $\begin{array}{c}8.4 \\
(0.12)\end{array}$ & $\begin{array}{l}31.26 \\
(2.54)\end{array}$ & $\begin{array}{c}8.32 \\
(0.11)\end{array}$ & $\begin{array}{l}27.25 \\
(1.05)\end{array}$ & $\begin{array}{c}8.2 \\
(0.14)\end{array}$ & $\begin{array}{l}23.25 \\
(1.05)\end{array}$ & $\begin{array}{c}8.14 \\
(0.17)\end{array}$ & $\begin{array}{l}26.47 \\
(2.05)\end{array}$ & $\begin{array}{c}8.05 \\
(0.11)\end{array}$ & $\begin{array}{l}19.45 \\
(1.03)\end{array}$ & $\begin{array}{c}8.47 \\
(0.20)\end{array}$ & $\begin{array}{l}30.82 \\
(1.52)\end{array}$ \\
\hline 72 & $\begin{array}{c}8.3 \\
(0.14)\end{array}$ & $\begin{array}{l}31.08 \\
(3.04)\end{array}$ & $\begin{array}{c}8.27 \\
(0.15)\end{array}$ & $\begin{array}{l}22.08 \\
(3.35)\end{array}$ & $\begin{array}{c}8.1 \\
(0.17)\end{array}$ & $\begin{array}{l}15.72 \\
(2.08)\end{array}$ & $\begin{array}{c}8.02 \\
(0.13)\end{array}$ & $\begin{array}{l}19.48 \\
(1.08)\end{array}$ & $\begin{array}{c}7.92 \\
(0.20)\end{array}$ & $\begin{array}{l}12.18 \\
(1.64)\end{array}$ & $\begin{array}{c}8.32 \\
(0.10)\end{array}$ & $\begin{array}{l}23.15 \\
(1.58)\end{array}$ \\
\hline 96 & $\begin{array}{c}8.2 \\
(0.21)\end{array}$ & $\begin{array}{l}30.27 \\
(2.45)\end{array}$ & $\begin{array}{c}8.13 \\
(0.23)\end{array}$ & $\begin{array}{l}16.48 \\
(2.95)\end{array}$ & $\begin{array}{c}8.0 \\
(0.11)\end{array}$ & $\begin{array}{c}7.08 \\
(1.52)\end{array}$ & $\begin{array}{c}8.03 \\
(0.15)\end{array}$ & $\begin{array}{l}12.78 \\
(2.05)\end{array}$ & $\begin{array}{c}7.83 \\
(0.10)\end{array}$ & $\begin{array}{c}4.05 \\
(1.17)\end{array}$ & $\begin{array}{c}8.25 \\
(0.21)\end{array}$ & $\begin{array}{l}16.24 \\
(1.39)\end{array}$ \\
\hline 102 & $\begin{array}{c}8.2 \\
(0.22)\end{array}$ & $\begin{array}{l}29.72 \\
(2.06)\end{array}$ & $\begin{array}{c}8.05 \\
(0.16)\end{array}$ & $\begin{array}{c}7.05 \\
(1.85)\end{array}$ & $\begin{array}{c}7.9 \\
(0.23)\end{array}$ & $\begin{array}{c}2.08 \\
(1.62)\end{array}$ & $\begin{array}{c}7.92 \\
(0.22)\end{array}$ & $\begin{array}{c}3.08 \\
(1.04)\end{array}$ & $\begin{array}{c}7.84 \\
(0.25)\end{array}$ & $\begin{array}{c}0.18 \\
(0.05)\end{array}$ & $\begin{array}{c}8.23 \\
(0.22)\end{array}$ & $\begin{array}{l}11.75 \\
(1.05)\end{array}$ \\
\hline
\end{tabular}

Each is the mean of three replicates, and values in parenthesis indicate standard deviation. SDS contaminated water without vegetation and bacteria (C), SDS contaminated water with $L$. fusca (T1), SDS contaminated water with $L$. fusca and bacteria (T2), SDS contaminated water with B. mutica (T3), SDS contaminated water with vegetation (B. mutica) and bacteria (T4), and SDS contaminated water with bacteria (T5).

\subsection{Persistence of Inoculated Bacteria in FTWs}

In phytoremediation, plant-bacteria synergism plays a key role in the degradation of organic contaminants. It has been proposed that the ability of a plant to remediate water is directly related to a number of the contaminants-degrading bacterial population in its different compartments [42,57]. In this study, the persistence of inoculated bacteria was determined in the water as well as the roots and shoots of the plants. In the water from unvegetated treatment (T5), a relatively lower number of inoculated bacteria were found as compared to the water collected from the treatment having vegetation (T2 and T4). This might be due to the lack of mutualistic partnership between the plant and bacteria. The plant provides nutrients, oxygen, and shelter to the residing microorganisms thus allow them to grow, proliferate, and nurture [42,57].

The survival and colonization of inoculated bacteria in the FTWs is highly crucial for efficient degradation of the contaminants [42]. In this study, inoculated bacteria showed survival in the root and shoot interiors of B. mutica and L. fusca. This could be due to the fact that all of the inoculated bacteria were previously isolated from the rhizosphere, roots, and shoots of the wetland plants. Therefore, they might have developed necessary mechanisms to colonize the plant interior for B. mutica and L. fusca as well $[35,36,41,42,57]$. Further, we observed that the bacterial population in the root interior was significantly higher than that of the shoot interior of both plants. The higher population in the roots could be attributed to the fact the inoculated strains were often observed in the rhizospheric and root interior of the wetland plants in earlier studies, which suggest their better colonization potential in the root environment compared to the shoot [52]. Also, in this study, the observations were made after a few days only and the time might not have been sufficient for the active migration of the bacterial communities to the aboveground tissues. Many earlier studies also demonstrated that a higher number of the inoculated bacteria was found in the root interior than the shoot interior [40-42]. Between two plants, the more bacterial population was observed in the root, shoot, and water of the FTWs vegetated with $B$. mutica than $L$. fusca (Table 2). This indicates that B. mutica is a more suitable host for the inoculated bacterial community than the L. fusca. Many earlier studies also reported that different plant species hosted different numbers of bacteria in their different compartments $[42,43]$. 
Table 2. Persistence of the inoculated bacteria in the water, root interior, and shoot interior of Leptochloa fusca and Brachiaria mutica vegetated in FTWs.

\begin{tabular}{|c|c|c|c|c|}
\hline \multirow{2}{*}{ Treatment } & \multicolumn{4}{|c|}{ Time } \\
\hline & $\mathrm{Oh}$ & $48 \mathrm{~h}$ & $96 \mathrm{~h}$ & $102 \mathrm{~h}$ \\
\hline \multicolumn{5}{|c|}{ Water $\left(\mathrm{CFU} \mathrm{m} \mathrm{ml}^{-1}\right)$} \\
\hline L. fusca and bacteria & $8.2 \times 10^{5}\left(5.2 \times 10^{3}\right)$ & $5.0 \times 10^{3}\left(2 \times 10^{2}\right)$ & $4.0 \times 10^{2}\left(2.2 \times 10^{2}\right)$ & $1.5 \times 10^{2}\left(0.9 \times 10^{2}\right)$ \\
\hline B. mutica and bacteria & $8.2 \times 10^{5}\left(5.2 \times 10^{3}\right)$ & $7.3 \times 10^{3}\left(2.5 \times 10^{2}\right)$ & $9.1 \times 10^{2}\left(1.5 \times 10^{2}\right)$ & $2.1 \times 10^{2}\left(1.0 \times 10^{2}\right)$ \\
\hline Bacteria & $8.2 \times 10^{5}\left(5.2 \times 10^{3}\right)$ & $4.5 \times 10^{2}\left(1.2 \times 10^{2}\right)$ & $2.6 \times 10^{2}\left(1.0 \times 10^{2}\right)$ & $1.2 \times 10^{2}\left(0.8 \times 10^{2}\right)$ \\
\hline \multicolumn{5}{|c|}{ Root interior $\left(\mathrm{CFU} \mathrm{g}^{-1}\right)$} \\
\hline L. fusca and bacteria & - & $6.6 \times 10^{3}\left(2.3 \times 10^{2}\right)$ & $4.8 \times 10^{4}\left(2.2 \times 10^{2}\right)$ & $6.4 \times 10^{4}\left(2.7 \times 10^{2}\right)$ \\
\hline B. mutica and bacteria & - & $3.0 \times 10^{4}\left(1.8 \times 10^{2}\right)$ & $6.0 \times 10^{5}\left(4.3 \times 10^{2}\right)$ & $8.7 \times 10^{5}\left(6.2 \times 10^{2}\right)$ \\
\hline \multicolumn{5}{|c|}{ Shoot interior $\left(\mathrm{CFU} \mathrm{g}^{-1}\right)$} \\
\hline L. fusca and bacteria & - & $1.7 \times 10^{2}\left(0.9 \times 10^{2}\right)$ & $5.1 \times 10^{3}\left(2.6 \times 10^{2}\right)$ & $6.2 \times 10^{3}\left(3.5 \times 10^{2}\right)$ \\
\hline B. mutica and bacteria & - & $2.7 \times 10^{2}\left(1.1 \times 10^{2}\right)$ & $5.8 \times 10^{3}\left(3.0 \times 10^{2}\right)$ & $7.0 \times 10^{3}\left(1.1 \times 10^{2}\right)$ \\
\hline
\end{tabular}

\section{Conclusions}

This study establishes the usefulness of exploiting rhizospheric and endophytic bacteria in FTW in a partnership with two wetland plants namely B. mutica and L. fusca for reclamation of water contaminated with SDS. We argue that a traditional FTW can be an effective choice for enhanced SDS removal from the wastewater if well-screened bacterial communities are inoculated in the system. In this way, a successful attenuation in COD, BOD, and pollutant of interest (SDS) could be achieved in a very short time. This study also argues that, if inoculated bacteria are compatible with the host and do not compete for resources with each other, they can survive well in planta, support the host health, and improve pollutant degradation. The better performance of $B$. mutica nevertheless indicates that different plants have different capacity of effective plant-microbe interplay which should be investigated carefully before designing an experiment. In the end, this study strengthens the application of pollutant degrading bacteria in FTW for the remediation of water contaminated with organic compounds. Nevertheless, further studies on the activity of enzymes alkyl sulfatases for the degradation of SDS are suggested.

Author Contributions: Writing—original draft preparation, M.Y., Z.Z., E.I., M.T. and S.I.; writingreview and editing, M.A., E.I., and M.R.; supervision, M.A. and M.R. All authors have read and agreed to the published version of the manuscript.

Funding: This research was funded by Higher Education Commission (HEC), Pakistan, grant number 20-3854/R\&D/HEC/14/918).

Conflicts of Interest: The authors declare no conflict of interest.

\section{References}

1. Shahbazi, R.; Kasra-Kermanshahi, R.; Gharavi, S.; Moosavi-Nejad, Z.; Borzooee, F. Screening of SDS-degrading bacteria from car wash wastewater and study of the alkylsulfatase enzyme activity. Iran. J. Microbiol. 2013, 5, 153.

2. Ambily, P.; Jisha, M. Metabolic profile of sodium dodecyl sulphate (SDS) biodegradation by Pseudomonas aeruginosa (MTCC 10311). J. Environ. Biol. 2014, 35, 827. [PubMed]

3. Hosseini, F.; Malekzadeh, F.; Amirmozafari, N.; Ghaemi, N. Biodegradation of anionic surfactants by isolated bacteria from activated sludge. Int. J. Environ. Sci. Technol. 2007, 4, 127-132. [CrossRef]

4. Dereszewska, A.; Cytawa, S.; Tomczak-Wandzel, R.; Medrzycka, K. The effect of anionic surfactant concentration on activated sludge condition and phosphate release in biological treatment plant. Pol. J. Environ. Stud. 2015, 24, 83-91. [CrossRef]

5. Mazumder, D.; Mukherjee, S. Treatment of automobile service station wastewater by coagulation and activated sludge process. Int. J. Environ. Sci. Develop. 2011, 2, 64-69. [CrossRef]

6. Jakovljević, V.D.; Vrvić, M.M. The Potential Application of Selected Fungi Strains in Removal of Commercial Detergents and Biotechnology. In Application and Characterization of Surfactants; IntechOpen: London, UK, 2017; p. 233. [CrossRef] 
7. Guerrini, A.; Romano, G.; Ferretti, S.; Fibbi, D.; Daddi, D. A performance measurement tool leading wastewater treatment plants toward economic efficiency and sustainability. Sustainability 2016, 8, 1250. [CrossRef]

8. Muga, H.E.; Mihelcic, J.R. Sustainability of wastewater treatment technologies. J. Environ. Manag. 2008, 88, 437-447. [CrossRef] [PubMed]

9. Balkema, A.J.; Preisig, H.A.; Otterpohl, R.; Lambert, F.J. Indicators for the sustainability assessment of wastewater treatment systems. Urban Water 2002, 4, 153-161. [CrossRef]

10. Chen, K.-H.; Wang, H.-C.; Han, J.-L.; Liu, W.-Z.; Cheng, H.-Y.; Liang, B.; Wang, A.-J. The application of footprints for assessing the sustainability of wastewater treatment plants. J. Clean. Prod. 2020, 277, 124053. [CrossRef]

11. Paulo, A.; Plugge, C.; García-Encina, P.; Stams, A. Anaerobic degradation of sodium dodecyl sulfate (SDS) by denitrifying bacteria. Int. Biodeterior. Biodegrad. 2013, 84, 14-20. [CrossRef]

12. Headley, T.; Tanner, C. In Floating treatment wetlands: An innovative option for stormwater quality applications. In Proceedings of the 11th International Conference on Wetland Systems for Water Pollution Control, Indore, India, 1-7 November 2008; pp. 1101-1106.

13. Weragoda, S.; Jinadasa, K.; Zhang, D.Q.; Gersberg, R.M.; Tan, S.K.; Tanaka, N.; Jern, N.W. Tropical application of floating treatment wetlands. Wetlands 2012, 32, 955-961. [CrossRef]

14. Ladislas, S.; Gerente, C.; Chazarenc, F.; Brisson, J.; Andres, Y. Floating treatment wetlands for heavy metal removal in highway stormwater ponds. Ecol. Eng. 2015, 80, 85-91. [CrossRef]

15. Yousaf, S.; Andria, V.; Reichenauer, T.G.; Smalla, K.; Sessitsch, A. Phylogenetic and functional diversity of alkane degrading bacteria associated with Italian ryegrass (Lolium multiflorum) and Birdsfoot trefoil (Lotus corniculatus) in a petroleum oil-contaminated environment. J. Hazard. Mater. 2010, 184, 523-532. [CrossRef]

16. Olkowska, E.; Polkowska, Z.; Namiesnik, J. Analytics of surfactants in the environment: Problems and challenges. Chem. Rev. 2011, 111, 5667-5700. [CrossRef]

17. Yen Doan, T.H.; Minh Chu, T.P.; Dinh, T.D.; Nguyen, T.H.; Tu Vo, T.C.; Nguyen, N.M.; Nguyen, B.H.; Pham, T.D. Adsorptive removal of Rhodamine B using novel adsorbent-based surfactant-nodified alpha alumina nanoparticles. J. Anal. Methods Chem. 2020, 2020. [CrossRef] [PubMed]

18. Pham, H.D.; Dang, T.H.M.; Nguyen, T.T.N.; Nguyen, T.A.H.; Pham, T.N.M.; Pham, T.D. Separation and determination of alkyl sulfate surfactants in wastewater by capillary electrophoresis coupled with contactless conductivity detection after preconcentration by simultaneous adsorption using alumina beads. Electrophoresis 2021, 42, 191-199. [CrossRef] [PubMed]

19. Li, P.; Ishiguro, M. Adsorption of anionic surfactant (sodium dodecyl sulfate) on silica. Soil Sci. Plant Uutr. 2016, 62, 223-229. [CrossRef]

20. Kuppusamy, S.; Thavamani, P.; Venkateswarlu, K.; Lee, Y.B.; Naidu, R.; Megharaj, M. Remediation approaches for polycyclic aromatic hydrocarbons (PAHs) contaminated soils: Technological constraints, emerging trends and future directions. Chemosphere 2017, 168, 944-968. [CrossRef] [PubMed]

21. Rashed, M.N. Adsorption Technique for the Removal of Organic Pollutants from Water and Wastewater, Organic Pollutants—Monitoring, Risk and Treatment; IntechOpen: London, UK, 2013; pp. 167-194. [CrossRef]

22. Rasheed, T.; Bilal, M.; Nabeel, F.; Adeel, M.; Iqbal, H.M. Environmentally-related contaminants of high concern: Potential sources and analytical modalities for detection, quantification, and treatment. Environ. Int. 2019, 122, 52-66. [CrossRef]

23. Yaseen, Z.M.; Zigale, T.T.; Kumar, R.; Salih, S.Q.; Awasthi, S.; Tung, T.M.; Al-Ansari, N.; Bhagat, S.K. Laundry wastewater treatment using a combination of sand filter, bio-char and teff straw media. Sci. Rep. 2019, 9, 1-11. [CrossRef]

24. Ijaz, A.; Imran, A.; ul Haq, M.A.; Khan, Q.M.; Afzal, M. Phytoremediation: Recent advances in plant-endophytic synergistic interactions. Plant Soil 2016, 405, 179-195. [CrossRef]

25. Ojo, O.A.; Oso, B.A. Biodegradation of synthetic detergents in wastewater. Afr. J. Biotechnol. 2009, 8, 229-249. [CrossRef]

26. Sharman, S.H. Extensive biodegradation of synthetic detergents. Nature 1964, 201, 704-705. [CrossRef]

27. Khan, M.S.; Zaidi, A.; Wani, P.A.; Oves, M. Role of plant growth promoting rhizobacteria in the remediation of metal contaminated soils. Environ.Chem. Lett. 2009, 7, 1-19. [CrossRef]

28. Scott, M.J.; Jones, M.N. The biodegradation of surfactants in the environment. Biochimica et Biophysica Acta (BBA)-Biomembranes 2000, 1508, 235-251. [CrossRef]

29. Khan, S.; Afzal, M.; Iqbal, S.; Khan, Q.M. Plant-bacteria partnerships for the remediation of hydrocarbon contaminated soils. Chemosphere 2013, 90, 1317-1332. [CrossRef]

30. Abhilash, P.; Powell, J.R.; Singh, H.B.; Singh, B.K. Plant-microbe interactions: Novel applications for exploitation in multipurpose remediation technologies. Trends Biotechnol. 2012, 30, 416-420. [CrossRef] [PubMed]

31. Hodson, M.E. The need for sustainable soil remediation. Elements 2010, 6, 363-368. [CrossRef]

32. Verhoeven, J.T.; Meuleman, A.F. Wetlands for wastewater treatment: Opportunities and limitations. Ecol. Eng. 1999, 12, 5-12. [CrossRef]

33. Song, J.; Li, Q.; Dzakpasu, M.; Wang, X.C.; Chang, N. Integrating stereo-elastic packing into ecological floating bed for enhanced denitrification in landscape water. Bioresour. Technol. 2020, 299, 122601. [CrossRef]

34. Park, J.B.; Sukias, J.P.; Tanner, C.C. Floating treatment wetlands supplemented with aeration and biofilm attachment surfaces for efficient domestic wastewater treatment. Ecol. Eng. 2019, 139, 105582. [CrossRef] 
35. Rehman, K.; Imran, A.; Amin, I.; Afzal, M. Inoculation with bacteria in floating treatment wetlands positively modulates the phytoremediation of oil field wastewater. J. Hazard. Mater. 2018, 349, 242-251. [CrossRef] [PubMed]

36. Afzal, M.; Arslan, M.; Müller, J.A.; Shabir, G.; Islam, E.; Tahseen, R.; Anwar-ul-Haq, M.; Hashmat, A.J.; Iqbal, S.; Khan, Q.M. Floating treatment wetlands as a suitable option for large-scale wastewater treatment. Nat. Sustain. 2019, 2, 863-871. [CrossRef]

37. Colares, G.S.; Dell'Osbel, N.; Wiesel, P.G.; Oliveira, G.A.; Lemos, P.H.Z.; da Silva, F.P.; Lutterbeck, C.A.; Kist, L.T.; Machado, E.L. Floating treatment wetlands: A review and bibliometric analysis. Sci. Total Environ. 2020, 714, 136776. [CrossRef] [PubMed]

38. Yeh, N.; Yeh, P.; Chang, Y.-H. Artificial floating islands for environmental improvement. Renew. Sustain. Energy Rev. 2015, 47, 616-622. [CrossRef]

39. Hu, Z.; Li, D.; Guan, D. Water quality retrieval and algae inhibition from eutrophic freshwaters with iron-rich substrate based ecological floating beds treatment. Sci. Total Environ. 2020, 712, 135584. [CrossRef]

40. Afzal, M.; Rehman, K.; Shabir, G.; Tahseen, R.; Ijaz, A.; Hashmat, A.J.; Brix, H. Large-scale remediation of oil-contaminated water using floating treatment wetlands. NPJ Clean Water 2019, 2, 3. [CrossRef]

41. Hussain, Z.; Arslan, M.; Malik, M.H.; Mohsin, M.; Iqbal, S.; Afzal, M. Treatment of the textile industry effluent in a pilot-scale vertical flow constructed wetland system augmented with bacterial endophytes. Sci. Total Environ. 2018, 645, 966-973. [CrossRef]

42. Ijaz, A.; Shabir, G.; Khan, Q.M.; Afzal, M. Enhanced remediation of sewage effluent by endophyte-assisted floating treatment wetlands. Ecol. Eng. 2015, 84, 58-66. [CrossRef]

43. Karigar, C.; Rao, S. Role of microbial enzymes in bioremediation of pollutans. Enzyme Res. 2011, 2011805187. [CrossRef]

44. Hussain, Z.; Arslan, M.; Shabir, G.; Malik, M.H.; Mohsin, M.; Iqbal, S.; Afzal, M. Remediation of textile bleaching effluent by bacterial augmented horizontal flow and vertical flow constructed wetlands: A comparison at pilot scale. Sci. Total Environ. 2019, 685, 370-379. [CrossRef]

45. Nawaz, N.; Ali, S.; Shabir, G.; Rizwan, M.; Shakoor, M.B.; Shahid, M.J.; Afzal, M.; Arslan, M.; Hashem, A.; Abd-Allah, E.F. Bacterial augmented floating treatment wetlands for efficient treatment of synthetic textile dye wastewater. Sustainability 2020, 12, 3731. [CrossRef]

46. Chen, Z.; Cuervo, D.P.; Müller, J.A.; Wiessner, A.; Köser, H.; Vymazal, J.; Kästner, M.; Kuschk, P. Hydroponic root mats for wastewater treatment. Environ. Sci. Pollut. Res. 2016, 23, 15911-15928. [CrossRef] [PubMed]

47. Arslan, M.; Imran, A.; Khan, Q.M.; Afzal, M. Plant-bacteria partnerships for the remediation of persistent organic pollutants. Environ. Sci. Pollut. Res. 2017, 24, 4322-4336. [CrossRef] [PubMed]

48. Shahid, M.J.; Arslan, M.; Ali, S.; Siddique, M.; Afzal, M. Floating wetlands: A sustainable tool for wastewater treatment. Clean Soil Air Water. 2018, 46, 1800120. [CrossRef]

49. Lyu, J.; Lin, G.; Fan, Z.; Lin, W.; Dai, Z. Suitable plant combinations for ecological floating beds in eutrophic subtropical coastal wetlands under different salinities: Experimental evidences. Int. J. Environ. Sci. Technol. 2020, 17, 4505-4516. [CrossRef]

50. Mustafa, H.M.; Hayder, G. Recent studies on applications of aquatic weed plants in phytoremediation of wastewater. Ain Shams Eng. J. 2020. [CrossRef]

51. Sessitsch, A.; Coenye, T.; Sturz, A.; Vandamme, P.; Barka, E.A.; Salles, J.; Van Elsas, J.; Faure, D.; Reiter, B.; Glick, B. Burkholderia phytofirmans sp. nov., a novel plant-associated bacterium with plant-beneficial properties. Int. J. Syst. Evol. Microbiol. 2005, 55, 1187-1192. [CrossRef] [PubMed]

52. Fatima, K.; Afzal, M.; Imran, A.; Khan, Q.M. Bacterial rhizosphere and endosphere populations associated with grasses and trees to be used for phytoremediation of crude oil contaminated soil. Bull. Environ. Contam. Toxicol. 2015, 94, 314-320. [CrossRef]

53. Federation, Water Environmental, and APH Association. Standard Methods for the Examination of Water and Wastewater; American Public Health Association (APHA): Washington, DC, USA, 2005.

54. Rehman, K.; Imran, A.; Amin, I.; Afzal, M. Enhancement of oil field-produced wastewater remediation by bacterially-augmented floating treatment wetlands. Chemosphere 2019, 217, 576-583. [CrossRef]

55. Shehzadi, M.; Afzal, M.; Khan, M.U.; Islam, E.; Mobin, A.; Anwar, S.; Khan, Q.M. Enhanced degradation of textile effluent in constructed wetland system using Typha domingensis and textile effluent-degrading endophytic bacteria. Water Res. 2014, 58, 152-159. [CrossRef]

56. Skrzypiecbcef, K.; Gajewskaad, M.H. The use of constructed wetlands for the treatment of industrial wastewater. J. Water Land Dev. 2017, 34, 233-240. [CrossRef]

57. Tara, N.; Arslan, M.; Hussain, Z.; Iqbal, M.; Khan, Q.M.; Afzal, M. On-site performance of floating treatment wetland macrocosms augmented with dye-degrading bacteria for the remediation of textile industry wastewater. J. Clean Prod. 2019, 217, 541-548. [CrossRef]

58. Chaturvedi, V.; Kumar, A. Diversity of culturable sodium dodecyl sulfate (SDS) degrading bacteria isolated from detergent contaminated ponds situated in Varanasi city, India. Int. Biodeterior. Biodegrad. 2011, 65, 961-971. [CrossRef]

59. Usharani, J.; Rajasekar, T.; Deivasigamani, B. Isolation and characterization of SDS (sodium dodecyl sulfate) degrading organisms from SDS contaminated areas. Open Access Sci. Rep. 2012, 1, 1-4. [CrossRef]

60. Effendi, I.; Nedi, S.; Pakpahan, R. Detergent disposal into our environmentand its impact on marine microbes. In IOP Conference Series: Earth and Environmental Science; IOP Publishing: Bristol, UK, 2017; Volume 97, p. 012030. [CrossRef] 